kuLTura - мeDia- TeoLogia

ISSN 2081-8971

$2017 \mathrm{nr} 28$, s. 74-89.

Katarzyna Nowaczyk-Basińska, Uniwersytet im. Adama Mickiewicza w Poznaniu

\title{
Wizja nieśmiertelności Nikołaja Fiodorowa i wspótczesne projekty technologicznego uobecnienia po śmierci
}

\author{
Nikolay Fyodorov's Vision of Immortality \\ and Contemporary Projects of Technological Re-presentation after Death
}

\begin{abstract}
STRESZCZENIE:
W ARTYKULE PRZEDSTAWIAM WYBRANE WSPÓŁCZESNE PROJEKTY DOTYCZĄCE TECHNOLOGICZNIE KONSTRUOWANEJ NIEŚMIERTELNOŚCI I ZESTAWIAM JE Z MYŚLĄ DZIEWIĘTNASTOWIECZNEGO FILOZOFA

NikoŁaja Fiodorowa - NiESTRUdZONEGO PROPAGATORA IDEI WSKRZESZANIA ZMAREYCH.

FilOZOFIA FIOdOROWA, KTÓRA ZAMIAST
\end{abstract} KONTEMPLOWAĆ ZJAWISKA, POSTULUJE AKTYWNY UDZIAE W ICH TWORZENIU, ZNAJDUJE ZASKAKUJĄCE PRZEDŁUŻENIE W AKTUALNIE ROZWIJANYCH PROJEKTACH KULTUROWO-TECHNOLOGICZNYCH ZWIĄZANYCH Z PRZYWRÓCENIEM CIAŁU ŻYCIA. FIODOROW ŁĄCZYŁ W SPÓJNĄ I KOHERENTNA CAŁOŚĆ ZAEOŻENIA RELIGIJNE

I NAUKOWE, INACZEJ JEDNAK NIŻ XXI WIEK, KTÓRY

WYTRĄCA NIEŚMIERTELNOŚĆ Z ORBITY ROZWAŻAŃ RELIGIJNYCH I DUCHOWYCH, A ZACZYNA SZUKAĆ DLA NIEJ UZASADNIENIA W POSTĘPIE TECHNOLOGICZNYM, DYSKURSACH POST- I TRANSHUMANISTYCZNYCH ORAZ W MECHANIZMACH WOLNEGO RYNKU.

\section{SŁOWA KLUCZOWE:}

NIEŚMIERTELNOŚĆ, POSTHUMANIZM, TRANSHUMANIZM ZMARTWYCHWSTANIE, KRIONIKA, AWATAR, TECHNOKULTURA

\begin{abstract}
:
IN THE ARTICLE I AM PRESENTING THE SELECTED CONTEMPORARY PROJECTS OF TECHNOLOGICALLY CONSTRUCTED IMMORTALITY AND I AM CORRELATING THEM WITH A NINETEENTH-CENTURY PHILOSOPHY OF NiKolaY Fyodorov - A TIRELESS PROMOTER OF THE IDEA OF RESURRECTING OF THE DEAD. THE FyOdOROV'S PHILOSOPHY, WHICH INSTEAD OF CONTEMPLATING THE PHENOMENON CALLS FOR ACTIVE PARTICIPATION IN THEIR CREATION, IS A SURPRISING EXTENSION OF THE CURRENTLY DEVELOPED CULTURAL AND TECHNOLOGICAL PROJECTS RELATED TO RESTORTING LIFE TO THE BODY. IN A COHERENT AND CONSISTENT VISION FYODOROV COMBINES RELIGIOUS AND SCIENTIFIC ASSUMPTIONS DIFFERENTLY THAN THE TWENTY-FIRST CENTURY, WHICH STARTS LOOKING FOR THE JUSTIFICATION OF IMMORTALITY IN TECHNOLOGICAL PROGRESS, THE POST- AND TRANSHUMANIST DISCOURSES AND MECHANISMS OF THE FREE MARKET.
\end{abstract}

\section{KEYWORDS:}

IMMORTALITY, POSTHUMANISM, TRANSHUMANISM, RESURRECTION, CRYONICS, AVATAR, TECHNOCULTURE 
$\hat{S}$ mierć jest własnością, stanem uwarunkowanym przyczynowo, a nie jakością, bez której człowiek przestałby być tym, kim jest i kim być powinien" ${ }^{1}$ - to stwierdzenie, które redefiniuje klasyczne rozstrzygnięcia metafizyczne i wchodzi w ostry spór dotyczący sensu człowieczeństwa. Sformułował je w dziewiętnastym wieku rosyjski filozof Nikołaj Fiodorow, dla którego konieczność życia zakończonego w czasie stanowiła fatalne urojenie umysłu. Fiodorow łączył perspektywę religijną i naukową, przekonując, że każdy człowiek powinien zadbać o uzyskanie nieśmiertelności w wymiarze ziemskim, zarówno dla siebie jak i przodków. Echa myśli Fiodorowa odnaleźć można w wielu projektach technologicznego uobecnienia po śmierci realizowanych współcześnie na całym świecie. Kilka z nich, które przywołam w dalszej części tekstu, jest zwiastunem trendów, które pod wpływem rozwoju nauki i nowych technologii dopiero się kształtują i determinują rozmaite praktyki kulturowe.

\section{Zawieszenie pewności}

Dwudziesty pierwszy wiek przynosi znaczące, ciągle rozpoznawane dopiero przemiany w sposobie myślenia - od projektów wirtualnej transcendencji o nazwie Eterni.me i LifeNaut przez Ray’a Kurzweila i jego pomysły na nieśmiertelność budowane na koncepcji Singularity, aż po Instytut Krioniki zamrażający ciała w nadziei na ich technologiczne ożywienie. Interdyscyplinarne myślenie jest jedyną metodą uchwycenia zmian w otaczającej nas dynamicznej rzeczywistości. Dlatego właśnie na projekty technologiczno-naukowe proponuję spojrzeć nie tylko przez pryzmat współczesnych dyskursów filozoficznych, ale także rozpoznań i refleksji osadzonych w dziewiętnastym wieku. Przegląd najważniejszych zjawisk związanych z tematem technologicznej nieśmiertelności uzupełnię zatem o wskazanie na ich post- $\mathrm{i}$ transhumanistyczne założenia, a wizjonerską koncepcję Nikołaja Fiodorowa zestawię z obecnym technokulturowym otoczeniem.

Aktualne realizacje projektu nieśmiertelności są konsekwentnym przedłużeniem myśli i technologii głęboko zanurzonych $w$ historii. Uparte dążenie do przekroczenia nieprzekraczalnych granic jest wspólne dla średniowiecznych magów i szarlatanów, barokowych alchemików, nowożytnych medyków oraz współczesnych inżynierów, biotechnologów i informatyków. Tym, co ich różni, jest repertuar narzędzi możliwych do wykorzystania - słowem technokultura, która jest zmiennym środowiskiem dla niezmiennego dążenia. Choć interesująca jest historia rozwoju myśli związanych $\mathrm{z}$ technologicznym uobecnieniem po śmierci, skromny zakres tej pracy nie pozwala nawet na jej pobieżne prześledzenie. Jedyny związek z przeszłą myślą o nieśmiertelności chciałabym utrzymać poprzez filozofię przywołanego wcześniej Nikołaja Fiodorowa. Powody są przynamniej trzy. Fiodorow ze swoją bezkompromisową koncepcją jest w historii filozofii zjawiskiem tak odrębnym, że trudno znaleźć jego „duchowych ojców”2, a jego myśl

\section{N. Fiodorow, Filozofia wspólnego czynu, przeł. C. Wodziński i M. Milczarek, Kęty 2012, s. 412.}

2 M. Milczarek, dz. cyt., s. 50. Takiego określenia używa Michał Milczarek, kontynuując swą myśl: „Filozofia - i rosyjska i zachodnioeuropejska - była dla niego co najwyżej negatywną odskocznią, za pomocą której formułował on własne poglądy. Twierdził, że cała właściwie filozofia obrała błędną drogęe”. 
tym bardziej wyróżnia się oryginalnością. Ponadto głosił on niezwykle radykalne poglądy na temat nieśmiertelności, tak jak wielu współczesnych wizjonerów i inspiratorów nowego porządku świata - jak choćby Ray Kurzweil, Martine Rothblatt, Abrey de Grey, Dimitri Itskov, Chris Winter, Marius Ursache czy Steven Nowella. „Filozofia twórczości” (o której szerzej w dalszej części tekstu) Fiodorowa, która zamiast kontemplować zjawiska, postuluje aktywny udział w ich tworzeniu, znajduje zaskakujące przedłużenie w aktualnie rozwijanych projektach związanych z przywróceniem ciału życia. Co ważne jednak, wszystkie omawiane projekty znajdują się ciągle w fazie wypróbowywania możliwości, a nie osiągania końcowych rezultatów. Żadna z firm czy jednostek badawczych nie daje jeszcze całkowitej gwarancji powodzenia przedsięwzięcia technologicznej nieśmiertelności.

Śmierci być nie powinno ${ }^{3}$ - stwierdzenie to mogłoby pojawić się na wielu portalach internetowych promujących ideę nieśmiertelności obok haseł takich jak: Po prostu stań się nieśmiertelny! ${ }^{4}$ Przechowaj swoje wspomnienia na zawsze $!^{5}$ Możliwości kapsuły czasu są ograniczone tylko twoją wyobraźnią! ${ }^{6}$ Zatrzymaj swoje ciało i umysł dla przyszłych pokoleń! ${ }^{7}$ Teksty Fiodorowa czytać można także równolegle $\mathrm{z}$ takimi publikacjami jak Transcend. Nine steps to living well forever Raya Kurzweila czy Virtually human. The Promise - and the Peril - of Digital Immortality Martine Rothblatt. Zmienia się oczywiście język i technokulturowe otoczenie, idea jednak pozostaje niezmienna. „Świat nie jest pytaniem, lecz zadaniem do spełniania" - komentuje myśli Fiodorowa Michał Milczarek. Nieśmiertelność to cel, który powinien według filozofa uruchamiać całą moc twórczą człowieka: ,jego autonomię (duchowość), wolność (moralność), rozum (naukę), sprawność i skuteczność (życie społeczne)" ${ }^{8}$. To pomysł totalny angażujący w równym stopniu utylitarne rozwiązania nauki, co terapeutyczne osiągnięcia sztuki i religii, wzmocniony wiarą w czyn człowieka ${ }^{9}$. Trzeba zatem, w przekonaniu Fiodorowa, zanegować bezmyślny i śmiercionośny mechanizm przyrody - „twardej, substancjalnej i rządzonej koniecznymi prawami realności, utrzymującej swe ogólne zasady za sprawą nieustannego wypierania indywiduów, żyjącej dzięki śmierci”" ${ }^{10}$.

$3 \quad$ M. Milczarek, dz. cyt., s. 87.

4 Wersja archiwalna strony projektu Eterni.me: http://eterni.me/ (dostęp: 20.01.2015 r.).

5 Cytat pochodzi ze strony internetowej projektu MyLifeBits: http://research.microsoft.com/en-us/projects/mylifebits/ (dostęp: 16.01.2016 r.).

6 Cytat pochodzi ze strony internetowej projektu Elysium Space: http://elysiumspace.com/ (dostęp: 19.01.2016 r.).

7 Cytat pochodzi ze strony internetowej projektu LifeNaut: www.lifenaut.com/learn-more/ (dostęp: 16.01.2016 r.).

$8 \quad$ M. Milczarek, dz. cyt., s. 75.

$9 \quad$ Por. J. Dobieszewski, Nikołaj Fiodorow - ekscecy zmartwychwstania, w: J. Dobieszewski (red.), Wokó1 Szestowa i Fiodorowa. Almanach myśli rosyjskiej, Ośrodek Wydawniczo-Poligraficzny SIM, Warszawa 2007, s. 76 .

Tamże, s. 78. 
Czas pokazuje jak swobodny jest przepływ myśli i dokonań z obszaru fiction do science. Wiele inicjatyw, które współcześnie zaczynają być realizowane w jednostkach naukowych, stanowiły kiedyś zaledwie wizjonerskie założenia postępu naukowego Fiodorowa lub były tematem futurystycznych narracji autorstwa Stanisława Lema, Philipa Dicka, Isaaca Asimova czy Larry'ego Nivena. Obecnie projekty dotyczące nieśmiertelności to spotkanie nauki eksplorującej nieznane dotąd obszary oraz kultury, która pozostając z nauką w bardzo silnych, symbiotycznych związkach, negocjuje znaczenia, a także eksperymentuje z nowymi sposobami myślenia i zachowania.

\section{Obowiązek moralny?}

W tekście Postawa horyzontalna i wertykalna - śmierć i życie Nikołaj Fiodorow wraca do momentu, kiedy człowiek porzuca świat zwierzęcy i zyskuje świadomość własnej śmiertelności ${ }^{11}$. Było to, według filozofa, związane z przyjęciem postawy wertykalnej i oddzieleniem się od nieświadomej i śmiercionośnej przyrody. Rosyjski myśliciel stwierdza, że „pierwszym aktem samostwarzania człowieka jest jego postawa wertykalna” ${ }^{12}$. Jak zauważa Milczarek teza ta ma ogromną wagę, gdyż oznacza, że człowiek powstał dzięki własnej woli i zaczął kształtować tym samym swój los i wyznaczać kierunki rozwoju ${ }^{13}$. Fiodorow uznał człowieka za istotę działającą o ogromnym potencjale kreacyjnym, a jego wysiłek i pracę za nieustanne odraczanie śmierci. Dlatego właśnie w stosunku do myśli „Moskiewskiego Sokratesa” (jak nazywa Fiodorowa Siergiej Bułgakow) używa się określenia „filozofia twórczości”, które explicite pojawia się dopiero u Mikołaja Bierdiajewa. Jak tłumaczy Cezary Jędrysko: „Nazwa filozofia twórczości może być zwodząca, gdyż w swoim nadrzędnym sensie nie odnosi się do sytuacji estetycznej, relacji pomiędzy artystą a dziełem sztuki, lecz do relacji etycznej, relacji człowieka do Boga i człowieka do drugiej osoby, jak również do siebie samego. Kluczowe dla tematu pojęcie twórczości nie jest synonimem ani procesu twórczego, wytwarzania artefaktów, ani twórczości jako zbioru wytworów, osiągnięć człowieka. Jest próbą odpowiedzi na podstawowe pytanie o sens istnienia człowieka poprzez wskazanie na twórczość jako istotę i powołanie człowieczeństwa" ${ }^{14}$.

Aby twórczość mogła zaistnieć, potrzebne jest przekonanie o tym, że świat nie stanowi struktury bezwzględnie dopełnionej. Człowiek więc obciążony jest ogromną odpowiedzialnością działania i samostanowienia. Musi nieustannie podejmować wysiłek i pracę kreacyjną, by odraczać śmierć, która jest bezwzględnym złem. To nie wybór stawiany przez Fiodorowa, ale jedyne i najważniejsze wskazanie etyczne, skierowane do

\footnotetext{
11 Tekst ten został ciekawie omówiony przez Michała Milczarka. Zob. M. Milczarek, dz. cyt., s. 53-57.

12 N. Fiodorow, dz. cyt., s. 781.

13 M. Milczarek, dz. cyt., s. 61.

14 C. Jędrysko, Filozofowie tylko interpretowali świat, idzie jednak o to, aby go przemienić. Filozoficzny projekt Mikołaja Fiodorowa i Mikołaja Bierdiajewa, „Kultura i Wartości” 2013, nr 3(7), http://kulturaiwartosci.umcs.lublin.pl/wpcontent/uploads/2014/01/Cezar_Jedrysko_Filozofowie_tylko_interpretowali_swiat1.pdf (dostęp: 05.01.2016 r.).
} 

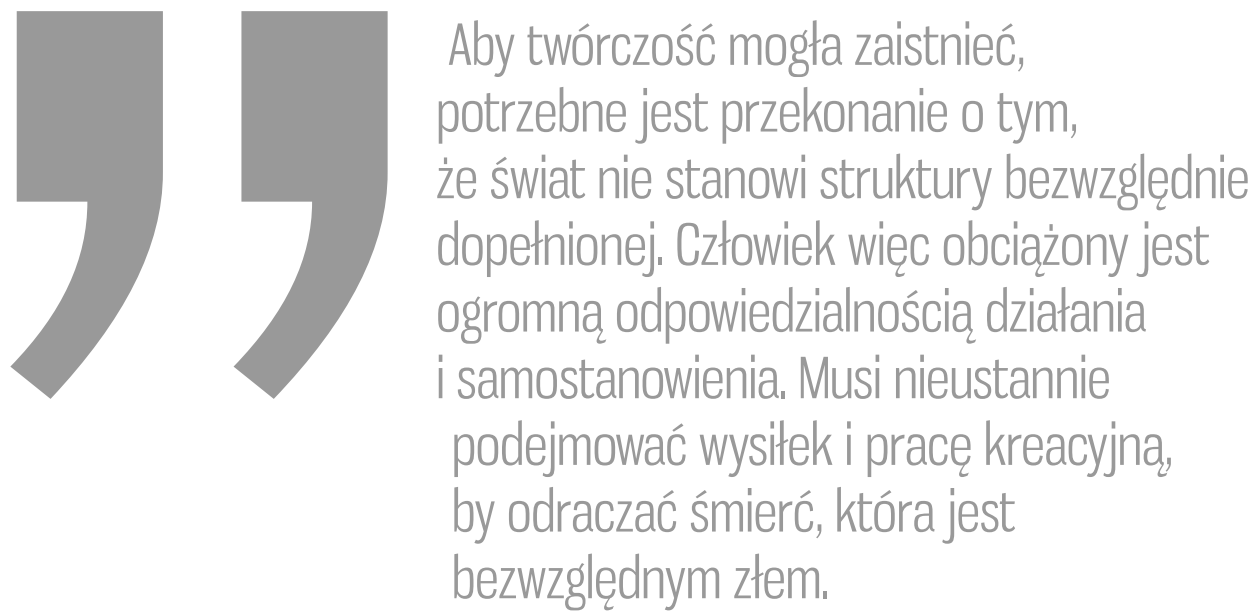

wszystkich, bez wyjątku, w poczuciu solidarności i jedności z obecnymi i przyszłymi pokoleniami. Dzięki postawie wyprostowanej człowiek zbliżył się do Boga i jednocześnie wyraził sprzeciw wobec ślepej i niebezpiecznej natury, choć stanowiąc jej część, nigdy nie wyzwolił się od niej całkowicie. „Postawa wertykalna była” - jaki pisał Fiodorow „wyrazem nieposłuszeństwa wobec przyrody oraz pokory w stosunku do Boga i zwrócenia się do Niego jako Kogoś ponad przyrodą" ${ }^{15}$. Człowiek zyskał jednocześnie druzgocącą wiedzę na temat skończoności własnego życia. Był zmuszony przyjąć tę wiadomość, ale nie godził się na nią ${ }^{16}$. Sprzeciw wobec śmierci, miał dla Fiodorowa charakter moralny i był podszeptem sumienia. Nie sposób według filozofa zaakceptować obowiązujące, naturalne prawo powszechnej śmiertelności, które wywołuje poczucie wszechogarniającego „kosmicznego smutku” - bolesnego, dojmującego i druzgocącego doświadczenia ułomności całego bytu.

W tej perspektywie niezwykle interesująca jest teza Fiodorowa o warunkowości apokalipsy, która przez wspomnianego Mikołaja Bierdiajewa została uznana jako „genialna i wyjątkowa w historii chrześcijaństwa" ${ }^{17}$. Fiodorow twierdził, że Apokalipsa św. Jana to rodzaj ostrzeżenia, a nie konieczności. Człowiek pozostając biernym, czyni Boga narzędziem realizowania własnych oczekiwań dotyczących zbawienia. Według Fiodorowa oczekiwanie na zmartwychwstanie to zaprzeczenie chrześcijańskiego przesłania i zaniechanie prób wyzwolenia się od bezwzględnego zła, jakim jest śmierć. Jak pisze Janusz Dobieszewski: ,,nie chodzi o zmartwychwstanie transcendentne, mistyczne, Boskie dla człowieka, ale immanentne, aktywne, Boskie, poprzez człowieka" ${ }^{18}$. To właśnie wskrzeszenie $^{19}$ jest centralną ideą filozofii Fiodorowa i właściwie sformułowanym zadaniem postawionym przed człowiekiem wierzącym. Obowiązek wyzwolenia się od śmier-

\footnotetext{
$15 \quad$ N. Fiodorow, dz. cyt., s. 785.

Podobną myśl wyrazi Zygmunt Freud w tekście Our Attitude Towards Death. Zob. www.nyu.edu/classes/gmoran/FREUD.pdf (dostęp 13.07.2016 r.). 
ci leży po stronie człowieka, który powinien połączyć perspektywę transcendentną z naukowym i technicznym projektem urzeczywistnienia idei nieśmiertelności. Koncepcja Fiodorowa wyrasta na fundamencie chrześcijaństwa, ale rosyjski myśliciel podkreśla również wielką rolę nauki i pracy twórczej, chcąc uniknąć zarzutów o mistycznej nieuchwytności swojego projektu. Moskiewski Sokrates znajdował inspiracje dla swoich zamierzeń między innymi w „działaniach ekologicznych, badaniach nad ludzką pamięcią, nad elektrycznością, nad wykorzystaniem energii słonecznej, zarządzaniu ruchem Ziemi i penetracją kosmosu, postępach w łączności i komunikacji, gromadzeniu informacji i rozwoju medycyny" ${ }^{20}$. Wiele z tych dziedzin, których rozwój antycypował Fiodorow, staje się podstawą tworzenia współczesnych koncepcji nieśmiertelności - w szczególności - ważne są tu kwestie: pamięci ludzkiej i technologicznie przedłużonej; gromadzenia, przechowywania, przetwarzania, udostępniania danych i włączania ich do komunikacyjnego obiegu; pracy nad możliwościami przywrócenia martwemu ciału funkcji biologicznych czy tworzenia nowych, bionicznych ciał zastępczych dla zmarłych. Fiodorow, w sposób niezwykle nowoczesny, wyrażał przekonanie, że ciało ma stać się naszym dziełem ${ }^{21}$. Właśnie w ciele widział on zapisaną możliwość pokonania śmierci, logicznie wynikającą z prawdy o tym, że człowiek został stworzony na podobieństwo Boga. Fiodorow znajdował głęboko religijne uzasadnienie dla ciała, które ma żyć wiecznie. Czy również o taką technologicznie konstruowaną nieśmiertelność walczy dwudziesty pierwszy wiek?

\section{Potencjalne możliwości}

Śledząc kierunki rozwoju projektów technologicznego uobecnienia po śmierci prowadzonych przez różne instytucje, firmy komercyjne czy jednostki badawcze, można wskazać trzy zasadnicze tendencje. Pierwsza możliwość dotyczy sytuacji, w której ciało biologiczne umiera, pozostaje natomiast cyfrowy odpowiednik zmarłego - awatar zarządzany przez algorytm sztucznej inteligencji. Projekt ten wymaga pracy przygotowawczej, jaką musi wykonać człowiek przed swoją śmiercią. Tak jest w przypadku amerykańskiego portalu Eterni.me, którego pomysłodawcą jest Marius Ursache ${ }^{22}$. Użytkownik profilu

19 Jak zauważa J. Dobieszewski: „Fiodorow wyraźnie odróżnia [...] zmartwychwstanie od wskrzeszenia [...]. Zmartwychwstały Chrystus wzywa człowieka do wskrzeszania przodków czego biblijnym wzorcem jest wskrzeszenie Łazarza. O ile zmartwychwstanie Chrystusa to owoc relacji między Bogiem-Ojcem, a wcielonym Bogiem-Synem, nieprzenikalny i nieosiągalny dla człowieka podobnie jak akt stworzenia (z nicości), o tyle wskrzeszenie Łazarza to wyraz najdoskonalszej relacji między Bogoczłowiekiem, a światem stworzonym, polegającej na odrodzeniu tego, co już istniało, wyrwaniu go śmierci; i właśnie to jest właściwym - choć zarazem ryzykownym, niepewnym, niezagwarantowanym - horyzontem człowieka, życia człowieka, aktywności człowieka, horyzontem zaspokajającym najdalsze ludzkie pragnienia oraz rozwiązującym zło i cierpienia świata, a osiąganym w procesie postępu ludzkiej wiedzy, nauki i techniki, współpracy i współdziałania”. J. Dobieszewski, dz. cyt., s. 72-73.

J. Dobieszewski, dz. cyt., s. 79. Zob. także: M. Milczarek, dz. cyt., s. 140-162.

21

22 O projekcie Eterni.me pisałam także w artykule Nieśmiertelność - nowy perfromans kulturowy? Zob.: K. Nowaczyk-Basińska, Nieśmiertelność- nowy performans kulturowy?, „Didaskalia” 2015, nr 130, 
kupuje dostęp do konta (do stworzenia pełnego profilu potrzeba 30-40 lat), a następnie dostarcza administratorom możliwie najwięcej śladów swojej aktywności w sieci - m.in. wpisy i zdjęcia umieszczone na Facebooku, wypowiedzi na forach internetowych, wiadomości email itp. System przetwarza te informacje, a algorytm sztucznej inteligencji doprowadza do ich „uczłowieczenia”. Jeszcze za życia nabywca profilu „doszkala” swojego pośmiertnego awatara, by ten stał się jego jak najbardziej wiarygodnym odpowiednikiem, który po biologicznej śmierci człowieka zostanie z rodziną. Nie chodzi zatem o podważenie śmierci i zachowanie biologicznego życia, ile o nowy sposób pamiętania o zmarłym. W tym przypadku z usługi korzystać będą najbliżsi zmarłego, a nie on sam.

W bliskim sąsiedztwie pojawiają się inicjatywy bardzo zbliżone w zamyśle do projektu Ursachego. Jednym z nich jest przedsięwzięcie badawcze MyLifeBits ${ }^{23}$ Gordona Bell'a $^{24}$, którego celem jest rozwijanie idei chatbota za pomocą oprogramowania IBM Cognea po to, by stworzyć cyfrową przestrzeń do kontaktu z człowiekiem na zasadzie skojarzeniowej. Zbieraniem informacji cyfrowej i próbą ich animacji w celu odtworzenia biologicznie istniejącego „sobowtóra” zajmują się także realizatorzy projektu LifeNaut (szerzej o projekcie w dalszej części tekstu).

Wskazane koncepcje mieszczą się w kręgach myśli posthumanistycznej. Posthumanizm wyrasta $\mathrm{z}$ klasycznych założeń humanizmu, które poddaje przekształceniom. Kwestie takie jak wiara, metafizyka, Bóg, nie są tu zanegowane, ale poszukuje się dla nich nowych znaczeń i relacji wobec pojawiających się w ich obrębie technologicznych uwarunkowań. „Jego głównym założeniem [posthumanizmu - przyp. KNB] jest zachowanie człowieka w jego istotowej postaci, to znaczy w jego biologicznych, kulturowych i metafizycznych ustaleniach, które mogą być technicyzowane tylko do pewnego stopnia. [...] Posthumanizm zawiera postulat maksymalnej humanizacji technicznego otoczenia człowieka. [...] posthumanizm kontynuuje i rozwija metafizykę w obliczu zmian wynikłych z postępu technologicznego. ${ }^{25}$.

s. 42-48. Zob. także: V. Birzoi, Marius Ursache, Eterni.me: "Our focus is on collecting, creating and curating a legacy for virtually every human”, http://blog.howtoweb.co/2014/12/marius-ursache-eternime-our-focus-is-on-collecting-creating-and-curating-a-legacy-for-virtually-every-human/ (dostęp: 03.01.2015 r.); K. Chayka, After Death, Don’t Mourn, Digitize With Sites Like Eterni.me, „Newsweek”, www.newsweek.com/2014/08/29/after-death-dont-mourn-digitize-sites-eternime-264892.html (dostęp: 03.01.2015 r.); L. Parker, How to Become Virtually Immortal, „The New Yorker”, www.newyorker.com/tech/elements/how-to-become-virtually-immortal (dostęp: 05.01.2015 r.). Informacje czerpię ze strony internetowej projektu: http://research.microsoft.com/en-us/projects/mylifebits/default.aspx [dostęp: 12.05.2015 r.]. MyLifeBits to eksperyment w dziedzinie life-logging i próba realizacji koncepcji Vannevara Busha - amerykańskiego inżyniera żyjącego na przełomie XIX i XX wieku, który w 1930 roku stworzył projekt o nazwie Memex. Miała to być nowa forma elektronicznej pamięci, która gromadzi informacje takie jak - książki, nagrania, konwersacje - a następnie w sposób automatyczny je wykorzystuje. Bush chciał, by Memex naśladował działanie ludzkiego mózgu na zasadzie skojarzeniowej, a nie indeksów i tradycyjnych, hierarchicznych zbiorów danych, a samo urządzenie traktował jako poszerzenie ludzkiej pamięci. 


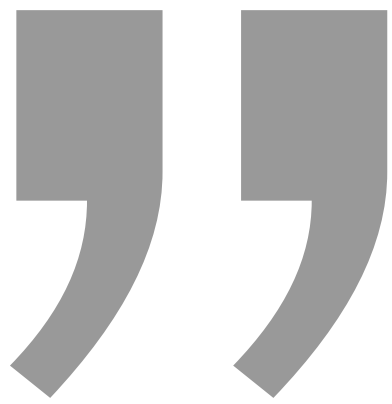

\section{Projekt Eterni.me oraz jemu pokrewne,} zakładające wirtualną transcendencje, próbują wprowadzić nowe modele zachowania. Prawa naturalne, jakim podlega ciało biologiczne, nie zostają tu naruszone, jedynie wobec zmarłego i jego rodziny buduje się wizję wiecznego trwania po śmierci. To jednak bardziej inicjatywa dotycząca nowego sposobu pamiętania i konstruowania pamięci o zmartym
niż projekt, który można nazwać w pełni
zapowiedzią wskrzeszenia człowieka.

Wobec takiej sytuacji istnieje potrzeba przemyślenia relacji z wirtualnym awatarem osoby zmarłej. Jaki jest jego status? Jak prawdziwe historie i wspomnienia zapisane na profilu Eterni.me przez zmarłego wpłyną na sposób korzystania z tej technologii przez rodzinę? Czy obcowanie z awatarem zmarłego podważa sens żałoby rozumianej jako przepracowanie straty i pożegnanie z tymi, którzy odeszli? Projekt Eterni.me oraz jemu pokrewne, zakładające wirtualną transcendencję, próbują wprowadzić nowe modele zachowania. Prawa naturalne, jakim podlega ciało biologiczne, nie zostają tu naruszone, jedynie wobec zmarłego i jego rodziny buduje się wizję wiecznego trwania po śmierci. To jednak bardziej inicjatywa dotycząca nowego sposobu pamiętania i konstruowania pamięci o zmarłym niż projekt, który można nazwać w pełni zapowiedzią wskrzeszenia człowieka. Jest on jednak ważnym pomostem prowadzącym do zrozumienia innych, bardziej radykalnych zamierzeń.

Druga możliwość bowiem wiąże się z zachowaniem ciała po śmierci. To propozycja sformułowana przez instytuty krioniki (m.in. Cryonics Institute. Technology for Life $^{26}$ czy Alcor. Life Extension Foundation ${ }^{27}$ ), które schładzają ciało nieżyjącej osoby do temperatury ciekłego azotu $\left(-196^{\circ} \mathrm{C}\right)$, by zachować je do czasu, kiedy nauka rozwinie się do tego stopnia, że możliwa będzie regeneracja bądź zastąpienie tkanek oraz przywrócenie im życia. Przechowanie zwłok w niskiej temperaturze zatrzymuje wszystkie biochemiczne reakcje ciała. Zmarłemu upuszcza się krew, a następnie używa się specjalnych krioprotektantów, które uniemożliwiają tworzenie się kryształków lodów, chroniąc

25 R. Ilnicki, Bóg cyborgów. Technika i transcendencja, Poznań 2011, s. 46 https://repozytorium.amu.edu.pl/bitstream/10593/4779/1/Rafal_Ilnicki.pdf (dostęp: 20.12.2015 r.).

26 Cryonics Institute. Technology for Life, http://www.cryonics.org/ (dostęp: 20.12.2015 r.).

27 Alcor. Life Extension Foundation, http://www.alcor.org/ (dostęp: 20.12.2015 r.). 
przed niszczeniem komórek. Ochłodzenie i utwardzanie bez zamrożenia, czyli fizycznego procesu formowania się lodu, to witryfikacja - termiczna przemiana substancji do szklistej postaci ${ }^{28}$. Następnie ciało pacjenta umieszcza się $w$ hermetycznie zamkniętym pojemniku ze stali nierdzewnej. Krionicy są zdania, że osoby uważane za martwe według obecnych standardów niekoniecznie muszą być uważane za nieżywe według standardów, które będą obowiązywać w przyszłości. W tym przypadku nauka ma dostarczyć narzędzi, by „wskrzesić” nieżyjące ciało. Sposób przywrócenia go do życia nie jest jeszcze znany.

I trzecia możliwość, której propagatorem jest między innymi Ray Kurzweil - wizjoner, naukowiec, wynalazca, założyciel wraz z NASA i Google, Instytutu Singularitis. Kurzweil uważa, że droga ku nieśmiertelności to proces trójstopniowy. Najpierw trzeba powstrzymać procesy starzenia ${ }^{29}$ reprogramując system biochemiczny, następnie dzięki biotechnologii trzeba podjąć próbę manipulacji w ludzkim DNA (perspektywa 15 lat), by w końcu w naszym mózgu mogły pojawić się nanoroboty, które zwiększą jego moc obliczeniową, zasoby pamięci i będą kontrolować cały organizm ${ }^{30}$. „Niebawem będziemy mieć dostęp do informacji w naszym mózgu, które konstytuują wspomnienia, zdolności i osobowość, a w związku z tym będziemy mieć także możliwość ich przywrócenia. Według mojego scenariusza nastąpi to w 2040 roku. Stanie się to dlatego, że w okolicy 2030 roku nasze procesy myślowe będą stanowić hybrydę tego, co biologiczne i tego, co nie-biologiczne"31.

Z Ray’em Kurzweilem współpracuje Martine Rothblatt - twórczyni przedsięwzięcia LifeNaut, założycielka fundacji Terasem Foundation oraz popularyzatorka idei nieśmiertelności. Naukowcy z LifeNaut opracowują metodę uzyskiwania tzw. Mindfiles (umysłowych plików, umysłowych baz danych), z których będzie można wykreować cyfrowego awatara - MindeClone - zdolnego do prowadzenia konwersacji. MindClone to: „Samoświadoma istota wirtualna, zdolna do myślenia, wyciągania wniosków, wspominania i odczuwania emocji. Mindclone będzie funkcjonalnie identyczny z umysłem biologicznym, istniejącym po prostu na innym podłożu - cyfrowym, a nie cielesnym. [...] Kiedy twoje ciało biologiczne umrze, ty będziesz żył wiecznie jako Mindclone" ${ }^{32}$.

28 Procedury te szczegółowo zostały opisane na stronie: www.cryonics.org/ci-landing/guide-to-cryonics-procedures/ (dostęp: 30.03.2016 r.), a także w artykule M. Powęska, Zamrożeni. Powstaną z martwych http://nt.interia.pl/raporty/raport-medycyna-przyszlosci/medycyna/news-zamrozeni-powstana-z-martwych,nId,1014385 (dostęp:30.03.2016 r.).

To również koncepcja dr Aubrey’a de Grey’a Zob.: A. Grey, Seeking for immortality, www.youtube.com/watch?v=T0lvxTm2iLg (dostęp: 7.01 .2016 r.).

R. Kurzweil, T. Grossman, Transcend. Nine Steps to Living Well Forever, Rodale Inc. New York, 2011, s. xx.

31 Ray Kurzweil jest autorem wstępu do książki M. Rothblatt, The Promise and the Peril of Digital Immortality. Zob.: www.amazon.com/Virtually-Human-Promise-Peril-Immortality ebook/dp/B00IM11FK8/ref=tmm_kin_swatch_0?_encoding=UTF8\&sr=\&qid=\#reader_B00IM11FK8 (dostęp: $13.05 .2015 \mathrm{r}$.). 
Obok Mindfiles, Terasam Foundation proponuje także program Biofiles. Na stronie internetowej znajduje się czteropunktowy opis tej procedury:

„1. Zapisz się do projektu Biofile. Nie pobieramy żadnych opłat, niemniej będziemy bardzo wdzięczni za twój podatek odliczany jako darowizna.

2. Następnie wyślemy ci butelkę do płukania jamy ustnej oraz probówki.

3. Wypłuczesz gardło i prześlesz nam zawartość. Zbierzemy żywe komórki i zamrozimy je w temperaturze ciekłego azotu $\left(-196^{\circ} \mathrm{C}\right)$ na czas nieokreślony.

4. Po tym, jak zostaniesz prawnie uznany za zmarłego, przyszła technologia będzie w stanie wytworzyć dla ciebie nowe ciało dzięki ektogenezie, a twoje Mindfiles (świadomość) będą możliwe do ściągnięcia i umieszczenia w nowym ciele, zapewniając tobie życie bez końca" ${ }^{33}$.

Rothblatt wraz z żoną, Bine Rothblatt prowadzą również projekt, którego celem jest stworzenie robota przechowującego wszelkie informacje o Binie. Powstały robot BINA48 ${ }^{34}$ to według Kurzweila: „zdumiewający przykład odtworzenia fizycznych i psychicznych możliwości ludzkiego umysłu w maszynie. Robot nie jest jeszcze klonem Biny, ale jej robotyczny awatar jest wspaniałą zapowiedzią tego, co nadchodzi ${ }^{35}$. Obie drogi ku technologicznej nieśmiertelności - pierwsza związana z krioniką i zamrażaniem ciała ludzkiego, druga z zaniechaniem procesów starzenia i tworzeniem biologiczno-technologicznych systemów utrzymujących życie człowieka w nieskończonym horyzoncie czasowym - wyrastają z gruntu transhumanistycznego. Projektowana jest tu nowa wizja świata oparta na ludzkich możliwościach i przekonaniu otym, że śmierć należy całkowicie wykluczyć z ludzkiego doświadczenia.

Nieśmiertelność - ciała i umysłu - to wizja totalna, łącząca dostępną wiedzą o ciele i zachodzących w nich procesach biologicznych z obecnymi osiąnnięciami technologicznymi; oparta jest także na przewidywaniach, że w niedalekiej przyszłości ludzkość dojdzie do punktu tzw. „technologicznej osobliwości” ${ }^{36}$ w której postęp techniczny prze-

33 Cytat pochodzi ze strony internetowej organizacji LifeNaut: www.lifenaut.com/learn-more-bio/ (dostęp: 13.05.2015 r.).

Opis projektu z najduje się na stronie: www.lifenaut.com/bina48/ (dostęp: 12.04.2015 r.).

35 R. Kurzweil, Wstęp, w: M.
lity, New York 2014, s. xii.

Już w latach osiemdziesiątych XX wieku Vernor Vinge wprowadził i rozpowszechnił pojęcie „osobliwości technologicznej”, w języku angielskim w całości tłumaczone jako technological singularitylub po prostu singularity. Technologiczna osobliwość to hipotetyczna wizja rozwoju cywilizacji, w której postęp techniczny stanie się tak szybki, że jakiekolwiek przewidywania ludzkie okażą się nieaktualne. Główną tego przyczyną miałoby być stworzenie sztucznej inteligencji, znacznie przewyższającej ludzkie zdolności, która będzie mogła się reprodukować i tworzyć jeszcze wydajniejsze systemy. Punkt, w którym człowiek straci zupełnie kontrolę nad stworzonymi technologiami, nazywany jest osobliwością. Ogromną rolę w formułowaniu koncepcji singularitis odgrywa Ray Kurzweil. Jego zdaniem można przewidzieć nadejście „ery osobliwości” datowanej na rok 2045, na podstawie analizy dotychczasowych trendów rozwoju oraz w oparciu o prawo Moore’a, które Kurzweil przenosi na obszar technologii. Będzie to, jak pisze w swojej książce, „okres w przyszłości, w którym tempo zmian technologicznych będzie tak szybkie, a jego wpływ tak głęboki, że życie ludzkie zmieni się w sposób nieodwracalny” Zob. R. Kurzweil, Nadchodzi osobliwość. Kiedy człowiek przekroczy granice biologii, 


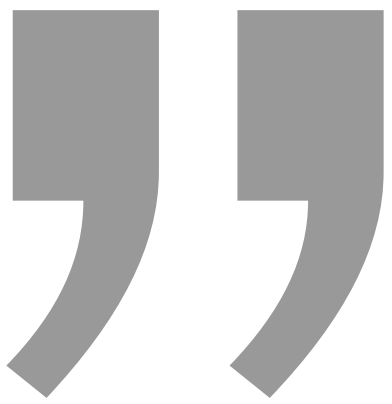

Transhumanistyczna zapowiedź

technologicznego uobecnienia po śmierci

to w istocie perspektywa, nieznanej

rzeczywistości, w której pojawia się nowy

człowiek przezwyciężający największe

dotychczasowe ograniczenie - własna śmierć.

W tej sytuacji wypracowane dotąd systemy

myślowe tracą swoją aktualność. Znaczące

przesunięcia będą zatem musiały się dokonać

w obrębie wielu dyskursów: teologicznego,

metafizycznego, naukowego, antropologicznego,

etycznego, psychologicznegó...

wyższy znacznie możliwości człowieka. Transhumanistyczna zapowiedź technologicznego uobecnienia po śmierci to w istocie perspektywa, nieznanej rzeczywistości, w której pojawia się nowy człowiek przezwyciężający największe dotychczasowe ograniczenie - własną śmierć. W tej sytuacji wypracowane dotąd systemy myślowe tracą swoją aktualność. Znaczące przesunięcia będą zatem musiały się dokonać w obrębie wielu dyskursów: teologicznego, metafizycznego, naukowego, antropologicznego, etycznego, psychologicznego...

Do takiego właśnie celu zmierzają również członkowie ruchu społecznego „Russia 2045”, którego inicjatorem jest miliarder Dimitri Itskov. Ich przedsięwzięcie zostało podzielone na cztery etapy. Pierwszy z nich - Awatar A - zakłada stworzenie antropomorficznego robota kontrolowanego przez interfejs mózg-komputer w perspektywie najbliższych czterech lat; następnie naukowcy będą pracować nad powołaniem do 2025 roku autonomicznego systemu, połączonego z Awatarem A, wspierającego istotne funkcje mózgu (Awatar B); kolejna dekada to próba połączenia osobowości i świadomości oraz przeniesienia ich do „sztucznego” nosiciela i wreszcie Awatar D - faza kulminacyjna projektu wyznaczona na rok 2045 - przewiduje powstanie nieśmiertelnego ciała-hologramu. ${ }^{37}$ „Głównym celem projektu 2045 Initiative jest realizacja nowej strategii rozwoju ludzkości, która łączy się z globalnymi wyzwaniami cywilizacyjnymi, stworzenie

tłum. E. Chodkowska, A. Nowosielska i in., Kurhaus Publishing Kurhaus Media 2013, s. 23. Przyczyną tego zjawiska stanie się tak zwany wzrost wykładniczy (wynikający z prawa Moor’a), a nie linearny rozwój technologiczny, do jakiego przywykliśmy.

37 Szczegółowy opis poszczególnych etapów znajduje się na stronie: http://2045.com/ (dostęp: 20.03.2016 r.). 
optymalnych warunków sprzyjających duchowemu oświeceniu ludzkości oraz zaprojektowanie nowej futurystycznej rzeczywistości opartej na pięciu zasadach: wysokim poziomie duchowości, kultury, etyki, nauki i technologii” ${ }^{38}$.

W lutym 2012 roku w Moskwie, a w 2013 roku w Nowym Jorku został zorganizowany przez Itskova międzynarodowy kongres Global Future 2045, który miał zaowocować powstaniem sieci kontaktów pomiędzy biologami, socjologami, antropologami, filozofami, by możliwa stała się praca nad wspólną strategią rozwoju ludzkości w związku z cybernetyczną nieśmiertelnością. Wśród licznego grona zaproszonych gości byli także wspomniani: Martine Rothblatt, Ray Kurzweil, a także Marvin Minsky - współzałożyciel laboratorium sztucznej inteligencji w Massachusetts Institute of Technology, zajmujący się naukami kognitywnymi czy Hiroshi Ishiguro - specjalizujący się w tworzeniu humanoidalnych robotów ${ }^{39}$. Interesujący jest fakt, że w kongresie brali udział także duchowni reprezentujący różne wyznania i kultury, a wśród nich Dalajlama, który wyraził poparcie dla projektu Itskova, zwracając uwagę na to, że nowoczesna technologia musi rozwijać się równolegle z nauką o człowieku.

\section{Pytania (nie tylko retoryczne)}

Nieśmiertelność to „technologia do pomyślenia” (określenie przywołuję za Stanisławem Lemem ${ }^{40}$ ), która zredefiniowałaby obecną metanarrację o człowieku i świecie. Nikołaj Fiodorow, uważany zresztą za prekursora transhumanizmu, również zmierzał do wielkiej syntezy, łącząc rozmaite interdyscyplinarne narracje i podporządkowując je rygorowi wewnętrznej koherencji i spójności ${ }^{41}$. Konieczna w tym miejscu jest jeszcze jedna uwaga.

O ile pęd dwudziestego pierwszego wieku ku nieśmiertelności byłby dla Fiodorowa przejawem wmyślenia się w filozofię wspólnego czynu, o tyle uwikłanie zagadnienia życia wiecznego w mechanizmy wolnorynkowe i konsumpcjonistyczne byłyby dla niego nie do zaakceptowania. Stroniąc od popularności, nie zgadzając się na odpłatny druk swoich nielicznie spisanych myśli, pomagając bezwarunkowo biednym, również ideę wspólnego czynu chciał uchronić przed wpływem praw popytu i podaży. Krytykował współczesny sobie konsumpcjonizm, starając się propagować raczej „ludowy” punkt widzenia - stając po stronie „niewykształconych” (lud wiejski) zwracał się do „wykształconych” (lud miejski), by ci ostatni przyłączyli się do bezinteresownego przeobrażania świata w imię wspólnego dobra. Dwudziesty pierwszy wiek szczyci się hasłami demokratyzującymi idee technologicznego uobecniania po śmierci, niewiele ma to jednak wspólnego $\mathrm{z}$ bezinteresownym wspólnym czynem. Nieśmiertelność to, w zdecydowanej większości przypadków, usługa

\footnotetext{
38 Cytat pochodzi ze strony internetowej organizacji Russia 2045: http://2045.com/dialogue/29819.html (dostęp: 20.03.2016 r.).

39 Pełna lista zaproszonych na kongres naukowców, przedsiębiorców i duchownych znajduje się pod linkiem: http://gf2045.com/speakers/ (dostęp: 20.04.2016 r.).

40 Zob. S. Lem, Summa technnologiae, Biblioteka Gazety Wyborczej, Warszawa 2010, s. 16.

41 Por. M. Milczarek, dz. cyt., s. 12.
} 

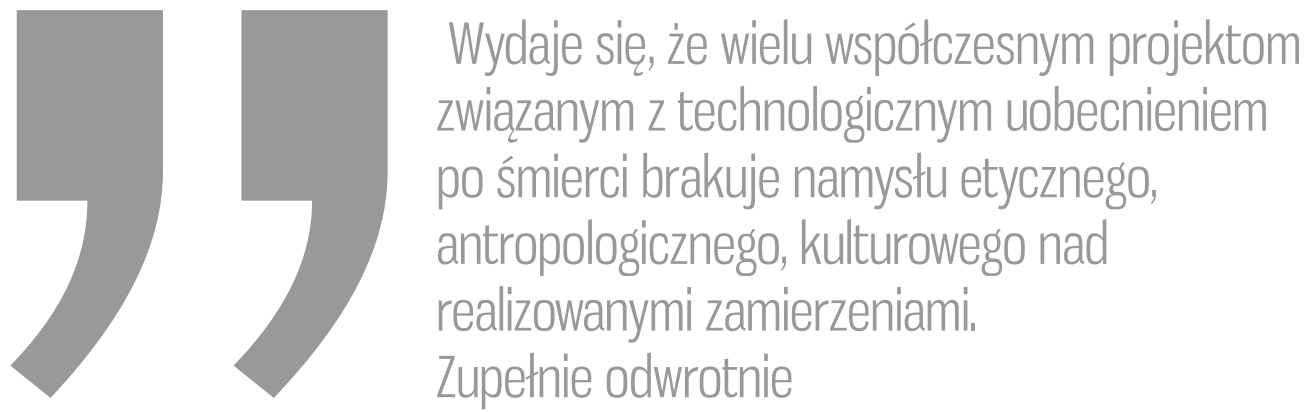

\section{sprawa wyǵląda u Fiodorowa.}

podporządkowana prawom wolnego rynku, mechanizmom sprzedażowym i marketingowym. O dostępie do niej decyduje status materialny potencjalnego klienta i jego zdolność do cią̧łego odnawiania swojego „nieśmiertelnego” konta założonego w danej firmie, regularnego płacenia abonamentu za usługę czy wpłacenia konkretnej sumy na konto danej instytucji gwarantującej, z odpowiednimi zastrzeżeniami zawartymi w regulaminie, zmartwychwstanie po śmierci.

Wydaje się, że wielu współczesnym projektom związanym z technologicznym uobecnieniem po śmierci brakuje namysłu etycznego, antropologicznego, kulturowego nad realizowanymi zamierzeniami. Zupełnie odwrotnie sprawa wygląda u Fiodorowa jego wszechstronna refleksja etyczna i religijna jest znacznie ciekawsza (i do pewnego stopnia nawet przekonująca) niż naukowe uzasadnienie jego własnych teorii, co oczywiście wynika również ze stanu wiedzy dziewiętnastowiecznej, do której dostęp miał Fiodorow. Nieśmiertelność to ogromne przedsięwzięcie myślowe, technologiczne i nieprawdopodobna odpowiedzialność, wielkie wyzwanie dla ludzkiej moralności. Czy wystarczy argumentów, by przyjąć tę odpowiedzialność? „Rosyjski myśliciel nie zadaje pytań innych niż retoryczne [...]. Wie, co należy myśleć i wie, co należy czynić. [...] Filozofia „wspólnego czynu” nie jest kolejną teorią opisującą świat, lecz wezwaniem do gruntownego przeobrażenia. Wezwaniem do wskrzeszenia wszystkich zmarłych. Przyjmuje przeto formę zwrotu do czytelnika, pragnie przekonać go do podjęcia tego wyzwania, jest bezustannie ponawianym apelem do jego sumienia". ${ }^{42}$ Fiodorow nie pytał o słuszność swojego projektu - znajdując logiczne i konsekwentne uzasadnienie moralne i religijne - a jedynie o sposób jego realizacji. Jakie zatem pytania powinno się postawić z perspektywy dwudziestego pierwszego wieku?

\section{Zakończenie}

Współczesność nieustannie przewartościowuje oswojone kategorie humanitas, redefiniując tym samym klasyczne rozstrzygnięcia metafizyczne. W tym nowym horyzoncie myślowym rozróżnienie na żywe i nie-żywe, realne i wirtualne, ludzkie i nie-ludzkie zaczyna tracić swoją wyrazistość, wchodząc w ostry spór z dotychczasową tradycją. Grani-

\footnotetext{
$42 \quad$ Tamże, s. 49.
} 
ce życia i śmierci zaczynają konstytuować się na nowo. Otwiera się przestrzeń dla eksperymentu, w którym śmierć biologiczna oznaczać może niebawem tylko „zmianę statusu" - z realnego $w$ wirtualny lub inny postbiologiczny stan istnienia, gdzie poszerzeniem i przedłużeniem ciała jest technologia przywracająca jego funkcje życiowe. Jesteśmy w momencie, w którym cyfrowa aktywność po śmierci przestaje być jedynie filozoficznym fantazmatem, a staje się coraz bardziej realną propozycją znajdującą swoje podstawowe uzasadnienia w technokulturowym paradygmacie (uprawomocnionym przez D. Haraway i B. Latoura), a także zwrocie cyfrowym charakteryzującym ostatnie dwie dekady. Nie bez znaczenia pozostają również ciągle rozwijające się badania w nurcie transhumanizmu, które zmierzają do odroczenia, a w przyszłości całkowitego przezwyciężenia śmierci.

Dwudziesty pierwszy wiek odważnie formułuje propozycje związane z unieśmiertelnieniem człowieka. W wyścigu o „lepsze jutro” w czołówce znajdują się Stany Zjednoczone, dla których projekt nieskończonego życia wyrasta z pragmatycznych założeń. Amerykanie nastawieni są na działanie - just do it - pojawia się wizja, więc trzeba poszukać możliwości finansowych i technologicznych, by można ją było zrealizować. Śmierć wydaje się momentem arbitralnie wyznaczonym tylko ze względu na technologiczne ograniczenia. Idea postępu napędza nawet najbardziej kontrowersyjne pomysły, a dobry plan ekonomiczno-marketingowy staje się dźwignią do osiągania odległych celów. Przekroczenie biologicznych i kulturowych uwarunkowań jest tu bardziej domeną rynku aniżeli filozofii ${ }^{43}$. Obok Stanów Zjednoczonych niekwestionowanym potentatem idei nieśmiertelności jest Rosja. Zwolennicy społecznego ruchu Russian 2045, dla których immortalizm staje się nową ideologią „,chcą przynieść światu nieśmiertelność tak, jak Rosja miała przynieść światu komunizm"44.

Fiodorow tworzył nową filozofię i koncepcję człowieka, który ulega przebóstwieniu, wtedy kiedy zmartwychwstaje tak jak Syn Boży. To radyklany pomysł o bardzo mocnych fundamentach religijnych. Dwudziesty pierwszy wiek stara się (z drobnymi wyjątkami) stopniowo wytrącać nieśmiertelność z orbity rozważań religijnych czy duchowych, a zaczyna szukać dla niej uzasadnienia jedynie w postępie technologicznym i popkulturowych rejonach ${ }^{45}$. Nieśmiertelność to barometr kulturowo-technologicznych zmagań, poligon psychologiczno-socjologicznych batalii oraz biznes z gigantycznym potencjałem. To wreszcie temat silnie związany z nauką i tylko w takiej relacji - dynamicznej i ciągle aktualizującej się - możliwy do podjęcia w kolejnych rozważaniach.

43 O takim podejściu Stanów Zjednoczonych do tematu nieśmiertelności mówił prof. Zbigniew Mikołejko w Audycji Trójki Polskiego Radia, porównując kulturowe podłoża Ameryki i Europy. Zob.: www.polskieradio.pl/9/396/Artykul/415645,Marzenia-o-niesmiertelnosci [dostęp: 20.05.2015 r.].

44 Takiego sformułowania użyła doktor Elżbieta Olzacka na ogólnopolskiej konferencji naukowej Technologiczno-społeczne oblicza XXI wieku w ramach swojego wystąpienia: Od Homo sapiens do Homo immortalis, Idea nieśmiertelności w rosyjskich projektach filozoficznych i społeczno-politycznych. cje ostatniej dekady to m.in. film Transcendencja Wally Pfistera, serial Black Mirror Charlie Brookera, a także powieść Na razie żegnaj Laurie Frankel. 


\section{BIBLIOGRAFIA}

Ajdukiewicz K., Zagadnienia i kierunki filozofii, Wydawnictwo Antyk - Fundacja Aletheia, Kęty-Warszawa 2003.

Alcor Life Extension Foundation, www.alcor.org/ (dostęp: 20.12.2015 r.).

Birzoi V., Marius Ursache, Eterni.me: "Our focus is on collecting, creating and curating a legacy for virtually every human",

http://blog.howtoweb.co/2014/12/marius-ursache-eterni-me-our-focusis-on-collecting-creating-and-curating-a-legacy-for-virtually-everyhuman/ (dostęp: 03.01.2015 r.].

Chayka K., After Death, Don't Mourn, Digitize With Sites Like Eterni.me, „Newsweek”, www.newsweek.com/2014/08/29/after-death-dontmourn-digitize-sites-eternime-264892.html (dostęp: 03.01.2015 r.).

Cieśliński P., Będziemy nieśmiertelni, „Książki. Magazyn do czytania” http://wyborcza.pl/1,75475,11648327,Bedziemy_niesmiertelni.html (dostęp:18.01.2016 r.).

Cryonics Institute, www.cryonics.org/ (dostęp: 20.12.2015 r.).

Eterni.me, http://eterni.me/ (dostęp: 16.01 .2016 r.).

Fiodorow N., Filozofia wspólnego czynu, Wydawnictwo Marek Derewiecki, Kęty 2012.

Freud Z., Our Attitude Towards Death, www.nyu.edu/classes/gmoran/FREUD.pdf (dostęp: 13.07.2016 r.).

Grey A., Seeking for immortality, www.youtube.com/watch?v=T0lvxTm2iLg (dostęp: 7.01.2016 r.).

Ilnicki R., Bóg cyborgów. Technika i transcendencja, Wydawnictwo Naukowe Wydziału Nauk Społecznych UAM, Poznań 2011.

Jędrysko C., Filozofowie tylko interpretowali świat, idzie jednak o to, aby go przemienić. Filozoficzny projekt Mikołaja Fiodorowa i Mikołaja Bierdiajewa, „Kultura i Wartości” 2013, nr 3(7), http://kulturaiwartosci.umcs.lublin.pl/wp-content/uploads/2014/01/Cezar_Jedrysko_Filozofowie_tylko_interpretowali_swiat1.pdf (dostęp: 20.03.2016 r.).

Kurzweil R., Nadchodzi osobliwość. Kiedy człowiek przekroczy granice biologii, tłum. E. Chodkowska, A. Nowosielska i in., Kurhaus Publishing Kurhaus Media 2013.

Kurzweil R., Grossman T., Transcend. Nine Steps to Living Well Forever, Rodale Inc., New York 2011.

Lem S., Summa technnologiae, Biblioteka Gazety Wyborczej, Warszawa 2010. LifeNaut, www.lifenaut.com/learn-more/ (dostęp: 16.01.2016 r.). Milczarek M., Z martwych was wskrzesimy. Filozofia Nikołaja Fiodorowa, Wydawnictwo Uniwersytetu Jagiellońskiego, Kraków 2013.

MyLifeBits, http://research.microsoft.com/en-us/projects/mylifebits/ (dostęp: 16.01.2016 r.). 
Parker L., How to Become Virtually Immortal, „,The New Yorker”, www.newyorker.com/tech/elements/how-to-become-virtually-immortal (dostęp: 05.01.2015 r.).

Robarts S., Eterni.me will create a computer version of you for when you die, „Gizmag”, www.gizmag.com/eterni-me-death-avatar/31053/ (dostęp: 03.01.2015 r.).

Rothblatt M., Virtually human. The Promise - and the Peril - of Digital Immortality, Picador USA, New York 2014.

Wokół Szestowa i Fiodorowa. Almanach myśli rosyjskiej, red. J. Dobieszewski, Ośrodek Wydawniczo-Poligraficzny SIM, Warszawa 2007.

Ziemiński I., Metafizyka śmierci, WAM, Kraków 2010.

\section{OAUTORCE:I}

mgr Katarzyna Nowaczyk-Basińska - doktorantka w Instytucie Teatru i Sztuki Mediów na Uniwersytecie im. Adama Mickiewicza w Poznaniu. Jej zainteresowania badawcze związane są z posthumanistycznymi przekształceniami kategorii humanitas i współczesnymi koncepcjami technologicznie produkowanej nieśmiertelności. Publikowała m.in. $w$ „Didaskaliach”, „Czasie Kultury” ,Gazecie Wyborczej”. W 2014 r. stypendystka Ministra Nauki i Szkolnictwa Wyższego. Kontakt: Instytut Teatru i Sztuki Mediów Uniwersytetu im. Adama Mickiewicza w Poznaniu, ul. Fredry 10, Poznań. Mail: katarzyna_nowaczyk@outlook.com 